\title{
Rettelser til Kultur \& Klasse 47
}

I artiklen "Sproget og det ubevidste" af Jean Laplanche er samtlige pile og en enkelt ellipse beklageligvis faldet ud. Nedenfor føiger de involverede formler med de korrekte pile indtegnet. Læseren bedes selv overføre rettelserne til sit eksemplar af nummeret.

Side 40, linje 4 fra neden:

$$
\mathrm{A} \longleftrightarrow \mathrm{B}
$$

Si.te 43, linje 17 og 31 :

$$
\frac{S^{\prime}}{S} \times \frac{S}{S} \rightarrow S^{\prime} \times \frac{1}{S}
$$

Side 44, linje 14:

$$
\frac{S}{S} \times \frac{S^{\prime}}{S} \rightarrow
$$

Side 44, linje 3 fra neden:

$$
\frac{\mathrm{B}}{\text { tårer }} \times \frac{\mathrm{A}}{\mathrm{B}} \rightarrow \mathrm{A} \times \frac{1}{\text { tårer }}
$$

Side 45, linje 7:

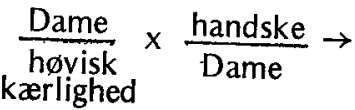

Side 46, linje 6:

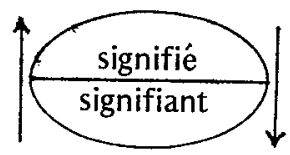

Side 60, linje 18:

$$
\frac{\mathrm{A}}{\mathrm{B}} \times \frac{\mathrm{C}}{\mathrm{A}} \rightarrow \text { ? }
$$

